\title{
Correlations between Thermal Environment and Egg Quality of Two Layer Commercial Strains
}

\begin{tabular}{l} 
- Author(s) \\
\hline Pereira $\mathrm{DF}^{1}$ \\
Vitorasso G \\
Oliveira $\mathrm{SC}^{3}$ \\
Kakimoto $\mathrm{SK}^{4}$ \\
Togashi CK \\
Soares NM ${ }^{6}$ \\
\\
1 Professor, Ph.D. Faculdade de \\
Administração de Empresas e Agronegócios, \\
Campus Experimental de Tupã - UNESP. \\
2 Undergraduate student, Faculdade de \\
Administração de Empresas e Agronegócios, \\
Campus Experimental de Tupã. \\
3 Professor, Ph.D., Faculdade de Administração \\
de Empresas e Agronegócios, Campus \\
Experimental de Tupã. \\
4 Researcher, APTA Alta Paulista. \\
5 Researcher, APTA Alta Paulista. \\
6 Researcher, Unidade Laboratorial de \\
\\
Patologia Avícola - Bastos - CAPTAA/B/APTA.
\end{tabular}

\section{Mail Address}

\author{
DF Pereira \\ Faculdade de Administração de Empresas e \\ Agronegócios, Campus Experimental de Tupã \\ - UNESP. \\ Av. Domingos da Costa Lopes, 780. \\ Jd. Unesp. \\ 17.602-496. Tupã, SP, Brazil \\ E-mail: danilo@tupa.unesp.br
}

\section{Keywords}

Cage, egg quality, environment, layer, poultry house.

\section{Acknowledgements}

The authors thank the Laboratory Unit of Avian Pathology of Bastos/CAPTAA/IB/APTA for the valuable contribution in egg quality analyses, the farm Kakimoto for allowing us to carry out this study in their facilities, FAPESP for the student grant (process n. 06/51926-7) and CNPq for funding the study (process n. 476397/ 20).

\section{ABSTRACT}

Heat stress limits the productivity of laying hens, as reflected by egg production and egg quality. The present study aimed at showing the correlations between egg quality parameters and environmental variables recorded on the day eggs were laid and on the previous days. Birds were housed in battery cages in a commercial poultry house. Main component analyses were used to verify associations between environmental and production variables, and Pearson's linear correlation tests were used to further investigate those associations. Analyses were carried out separately for to layer strains, Dekalb ${ }^{\circledR}$ White and Hy-Line ${ }^{\circledR}$ $w 36$, and the variables egg weight ( $g$ ), eggshell weight ( $g$ ), specific gravity $\left(\mathrm{g} / \mathrm{cm}^{3}\right)$ and eggshell percentage (\%) were compared with the environmental variables of the same day of the production, and one, two, three, and four days before egg production. Sound intensity measured inside the houses was positively associated with the quality parameters of eggs produced on the next day. Thermal environmental variables affected the egg quality differently in each strain, particularly air temperature, internal roof tile temperature, relative humidity, and air velocity. Ammonia concentration measured inside the houses was lower than $1 \mathrm{ppm}$, and did not affect production performance.

\section{INTRODUCTION}

Heat stress limits layer performance, as the bird diverts feed metabolic energy to maintain its body temperature constant, resulting in lower egg production, and particularly in lower egg quality (Esmay, 1982; Hsu et al., 1998; Teeter \& Belay, 1993; Tinôco, 2001).

Under high environmental temperatures, layer respiratory rate increases from approximately 29 cycles per minute (mild environmental temperatures) to more than 100 cycles per minute (environmental temperatures above the thermoneutral zone). The resulting hyperventilation decreases carbon dioxide blood levels, which may decrease eggshell thickness in approximately 12\% (Campos, 2000). Carbon dioxide is responsible for eggshell quality improvement, as it may promote acidosis, which is subsequently compensated by kidney uptake of bicarbonate. Therefore, heat stress causes losses in egg weight, eggshell percentage, eggshell weight, and egg specific gravity (Macari et al., 1994; Nääs, 1992).

Hsu et al. (1998) found that temperature increase significantly decreases feed intake, egg production, mean egg weight, and live weight, and also influence some egg quality traits, such as eggshell thickness and egg specific gravity. Muiruri \& Harison (1991) studied the performance of layers maintained under thermoneutral $\left(25^{\circ} \mathrm{C}\right)$ or hot $\left(35^{\circ} \mathrm{C}\right)$ temperatures, and concluded that environmental temperature did not influence egg weight or feed conversion ratio, but egg production 
and feed intake significantly decreased

As to environmental ammonia concentration, Nääs et al. (2007) and Wathes et al. (2002) found that ammonia concentrations higher than $20 \mathrm{ppm}$ may cause respiratory disease and affect egg production.

Studying the effects of light intensity on egg quality, Renema et al. (2001) observed a 12\% incidence of eggs below $55 \mathrm{~g}$ when light intensity was 500 lux, whereas no differences in egg weight were detected when light intensity was below 50 lux.

Due to the importance of the environment on layer productivity, this study evaluated the correlations between egg quality parameters and environmental variables recorded at the time of lay of two layer genetic strains housed in battery cages in a commercial layer house.

\section{MATERIALS AND METHODS}

The experiment was carried out in two layer houses of a commercial farm located in Bastos, SP, Brazil. The local climate is Cwa according to Köppen's classification, characterized by hot temperate climate, with a well-defined dry season in winter.

Data were recorded for 63 days (between March and May, 2007) divided in three cycles of 21 days each. Eggs for quality analyses were collected during the last three days of each cycle.

\section{Birds, cages, and houses}

A total number of 184 34-week-old layers belonging to two genetic strains (92 Dekalb ${ }^{\circledR}$ White and $92 \mathrm{Hy}$ Line ${ }^{\circledR}$ w36) were housed in wire cages.

In this experiment, houses were built in the eastwest direction, with the east and west walls closed with boards, and were not equipped with curtains. Roof material was different in each house. Both houses were equipped with wire battery cages, but with different dimensions. Chart 1 shows the main house characteristics and cage dimensions. Differences between houses and among cages were not tested.

Both houses operated as usual and housed 34-weekold Hy-Line ${ }^{\circledR}$ w36 layers. For the experiment, Hy-Line ${ }^{\circledR}$ w36 birds were removed from 16 cages (eight per house), with an approximate distance of $20 \mathrm{~m}$ from the west wall, which were used to house Dekalb ${ }^{\circledR}$ White layers of the same age. Other 16 cages (eight per house), at the same distance from the west wall, housed Hy-Line ${ }^{\circledR}$ w36 birds. All the experimental cages were monitored.

Cages closer to the center of the houses were monitored, with Dekalb ${ }^{\circledR}$ White birds housed closer to the north side of the barn and Hy-Line ${ }^{\circledR}$ w36 birds housed closer to the south side. Figure 1 shows the experimental layout of the cages inside the houses.
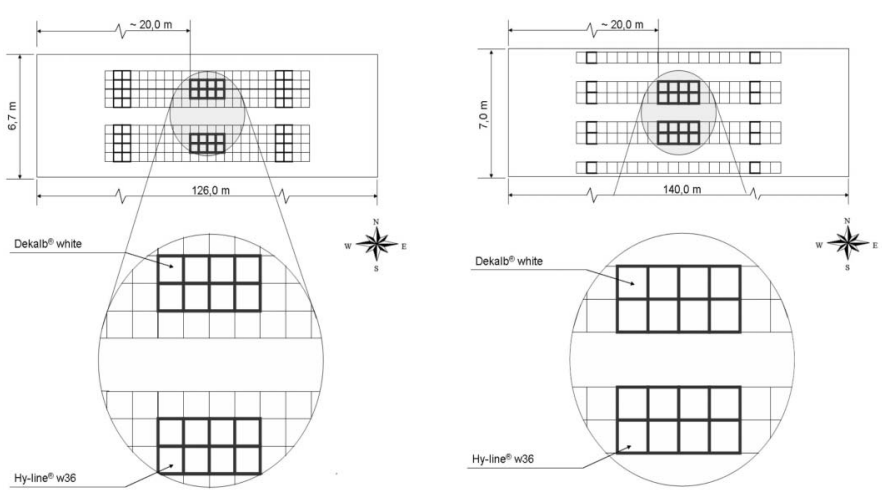

Figure 1 - Layout of the experimental setup in house 1 (a) and house 2 (b).

\section{Feeding management and lighting program}

A mixed artificial-natural lighting program was adopted. Lamps in both houses were lit at 04:00 am; during the day, natural lighting was used, and lights were turned on again at dusk and turned off at 09:00 pm, with a total period of light of $17 \mathrm{~h}$.

\begin{tabular}{|c|c|c|}
\hline Description & House 1 & House 2 \\
\hline Latitude & $21^{\circ} 57^{\prime} 30^{\prime \prime}$ & $21^{\circ} 57^{\prime} 29^{\prime \prime}$ \\
\hline Longitude & $50^{\circ} 42^{\prime} 05^{\prime \prime}$ & $50^{\circ} 42^{\prime} 03^{\prime \prime}$ \\
\hline Altitude & $444 \mathrm{~m}$ & $456 \mathrm{~m}$ \\
\hline Tiles & Asbestos with no external paint & Clay tiles with no external paint \\
\hline Chimney & Yes & No \\
\hline Roof extension & Yes & No \\
\hline Roof slope & $40 \%$ & $43 \%$ \\
\hline Height & $2.56 \mathrm{~m}$ & $2.32 \mathrm{~m}$ \\
\hline Width & $6.7 \mathrm{~m}$ & $7.0 \mathrm{~m}$ \\
\hline Length & $126.0 \mathrm{~m}$ & $140.0 \mathrm{~m}$ \\
\hline Distance between house floor and ground (foot height) & $2.0 \mathrm{~m}$ & $1.5 \mathrm{~m}$ \\
\hline Cage (width $\mathrm{x}$ depth $\mathrm{x}$ height) & $50 \mathrm{~cm} \times 45 \mathrm{~cm} \times 45 \mathrm{~cm}$ & $60 \mathrm{~cm} \times 60 \mathrm{~cm} \times 40 \mathrm{~cm}$ \\
\hline
\end{tabular}




\section{Pereira DF, Vitorasso G, Oliveira SC, Kakimoto SK, Togashi CK, Soares NM}

Feed $(17.8 \%$ protein and $2.750 \mathrm{kcal} / \mathrm{kg} \mathrm{ME}) \mathrm{had}$ the same formula during the entire experiment, and was fed ad libitum, according to the usual farm management. Daily feed intake was not monitored.

\section{Environment monitoring}

The following environmental variables were measured in a central point inside each house, in the corridor that separated the monitored cages, at brid height: air temperature, relative humidity, sound intensity, and light intensity (using a multi-function environmental analyzer, model THDL-400, manufactured by Instrutherm ${ }^{\circledR}$ ); air velocity (using a digital anemometer, model AN-3010 manufactured by Icel ${ }^{\circledR}$ ); internal roof tile temperature (infrared thermometer model Fluke66 manufactured by Fluke ${ }^{\circledR}$; and ammonia concentration (gas detector model PAC7000 $\mathrm{NH}_{3}$ manufactured by Drager ${ }^{\circledR}$ ).

\section{Egg quality analyses}

During the last three days of each production cycle, three eggs per cage were randomly collected. The following parameters were determined egg weight (EW, g), eggshell weight (ESW, g), specific gravity (SG, $\left.\mathrm{g} / \mathrm{cm}^{3}\right)$, and eggshell percentage (ES\%, \%) at the Laboratory Unit of Avian Pathology of Bastos, SP.

Eggs from each experimental unit were weighed in a $0.01-g$ precision scale, and then used for specific gravity determination by immersing the eggs in recipients containing different saline solutions, and recording the density in which the eggs floated. Saline solutions were adjusted with the aid of a densimeter, in concentrations between 1.062 and $1.098 \mathrm{~g} / \mathrm{cm}^{3}$, at 0.004 intervals.

Eggs were then broken for eggshell collection, which, after albumen and yolk removal, were dried in the air for 48 hours in the shade, and weighed. Eggshell percentage was calculated as the ratio between eggshell weight and egg weight.

\section{Statistical analysis}

Main component multivariate analysis was used to identify the associations between qualitative production parameters and house environmental variables.

The main component analysis is used to verify if there groups of associated variables and if typology evidences among variables can be detected (Johnson $\&$ Wichern, 1998). These relations among variables are evaluated with classic Euclidean distances in the case of comparison between individuals, and by correlation in the case of comparison between variables. In the present experiment, the main component analysis was applied to verify if the observed experimental variables were associated. The association of two variables $p$ and $\mathrm{q}$, of $\mathrm{n}$ sample sizes, can be calculated by the expression:

$$
\bar{X}_{p}=\sum_{i=1}^{n} p_{i} x_{i q} ; \quad r_{(p, q)}=\sum_{i=1}^{n} m_{i}\left(\frac{x_{i p}-\bar{x}_{p}}{s_{x p}}\right)\left(\frac{x_{i q}-\bar{x}_{q}}{s_{x q}}\right)
$$

Assuming that variables have the same importance $(m i=1 / n)$ in the present experiment, then:

$$
r_{(p, q)}=\frac{1}{n} \sum_{i=1}^{n}\left(\frac{x_{i p}-\bar{x}_{p}}{s_{x p}}\right)\left(\frac{x_{i q}-\bar{x}_{q}}{s_{x q}}\right) \text { (2) }
$$

Assuming that the variables are represented by vectors in $\mathfrak{R}^{n}$, the set of vector extremities that represent the variables is the cloud of points $N^{k}$, where $k$ is the number of studied variables. The main components are obtained by the orthogonal projection of the cloud of points $N^{k}$ along each main direction $u$. The coordinate of the ith individual in the new axis system (origin in $G$, e $u$ directions $\left\{u_{\alpha}, \alpha=1, \ldots, p\right\}$ ) is defined by the scale product $\left\langle w_{i}, u_{\alpha}\right\rangle$, where: $w_{i}=\left(\frac{x_{i 1}-\bar{x}_{1}}{S x_{1}}\right) e_{1}+\left(\frac{x_{i 2}-\bar{x}_{2}}{S x_{2}}\right) e_{2}+\ldots+\left(\frac{x_{i k}-\bar{x}_{k}}{S x_{k}}\right) e_{k_{i}}$ and the base $\left(e_{1}, e_{2}, \ldots, e_{k}\right)$ is an orthonormal base, centered in $G$.

This cloud of points $N^{k}$ is located in a hypersphere of radius 1 , defined in $\mathfrak{R}^{n}$, as it is impossible to study the cloud shape in $\Re^{n}(n>k)$ directly (Crivisqui, 1998). This means that the maximum number of components is defined by the number of studied variables.

When two main components are defined $\left(u_{1}, u_{2}\right)$ for a study, the inertia relative to the origin of the projection of the cloud of points is maximized (Crivisqui, 1998). As the norm of the vectors that represent the variables is equal to 1 , the projection coordinate of one variable over the other can be interpreted as the coefficient of correlation between the variables.

Therefore, for analyses of pairs of variables in the main component graphs, one must observe: 1) the magnitude of the vectors that summarize the variables in the plan, and which represents the contribution of these variables to the construction of the main 
components, and 2) the angle established by two vectors, as the projection of one vector over the other corresponds to the correlation between these variables. Johnson \& Wichern (1998) recommend that correlation tests are used together with main component analysis when data sets need to be further explored.

In the present study, five main component analyses were carried out for each genetic line with the objective of evaluating associations between egg quality parameters and environmental data obtained on the same day or on the days before the eggs were produced. These analyses are listed below.

- Main component analysis 1: egg qualitative parameters compared to environmental variables recorded on the same day eggs were produced;

- Main component analysis 2: egg qualitative parameters compared to environmental variables recorded the day before eggs were produced;

- Main component analysis 3: egg qualitative parameters compared to environmental variables recorded two days before eggs were produced;

- Main component analysis 4: egg qualitative parameters compared to environmental variables recorded three days before eggs were produced;

- Main component analysis 5: egg qualitative parameters compared to environmental variables recorded five days before eggs were produced.

Mean air temperature $\left(T,{ }^{\circ} \mathrm{C}\right)$, internal roof tile temperature (TTile, ${ }^{\circ} \mathrm{C}$ ), air horizontal velocity at bird height (AirV, $\mathrm{m} / \mathrm{s})$, relative humidity $(\mathrm{RH}, \%)$, sound intensity $(\mathrm{dB}, \mathrm{dB})$, and light intensity (Lux, lux), relative to daily measurement of environmental variables were calculated for main component analyses. In addition, maximum and minimum values of air temperature (Tmax; Tmin) and relative humidity (RHmax; RHmin) were determined.

All statistical analyses were carried out using Minitab ${ }^{\circledR}$ statistical software.

\section{RESULTS AND DISCUSSION}

Recorded ammonia concentration values were lower than 1ppm. According to Nääs et al. (2007) and Wathes et al. (2002), values above 20ppm may disturb bird behavior, and cause irritation of the respiratory system and egg production decline. Therefore, the ammonia values measured in the present experiment did not pose any risk to production. Air ammonia levels were low in the measured houses because the north and the south sides were completely opened, favoring natural ventilation, and because of distance of the floor from the ground, allowing the contaminated air below the floor to be renewed before ammonia reached the birds.

Analysis of variance (ANOVA) results showed significant differences between genetic strains $(P<$ 0.05 ) as to egg quality parameters, as found also by Franco-Jimenez et al.(2007). Therefore, analyses were carried out separately for each strain, which were submitted to five main component analyses to identify associations between qualitative production parameters and environmental variables.

Considering the main component analyses shown in Figures 2 and 3, a strong positive association of production parameters with internal roof tile temperature, air temperature, and light intensity in all analyses. Also, air relative humidity and sound intensity presented significant, but negative association. This association mimics what happens, for instance, when rain is about to fall, when heavy clouds appear in the sky, increasing air relative humidity at the same time that temperature and the intensity of the light that enters in the house decrease. Figure 1 shows the main component graphs for the environmental conditions on the same day of egg production of Dekalb ${ }^{\circledR}$ White (a) and Hy-Line ${ }^{\circledR}$ w36 (b) genetic strains.

Production parameters, despite presenting strong positive association among each other, did not present any association with environmental parameters measured on the same day of egg production (Figure 2 ), probably because the environmental variables measured on the same day eggs were produced had little or no influence on production. Table 1 shows the confidence interval for the mean of each environmental variable measured, determining the environmental conditions valid for the present study.

\begin{tabular}{lccc}
\hline $\begin{array}{l}\text { Table } 1 \text { - Confidence intervals and means of environmental } \\
\text { variables. } \\
\text { Lower limit }\end{array}$ & Mean Upper limit \\
Sound intensity $(\mathrm{dB})$ & 64.80 & 66.17 & 67.36 \\
Light intensity (lux) & 174.2 & 179.6 & 184.0 \\
Air velocity $(\mathrm{m} / \mathrm{s})$ & 0.163 & 0.300 & 0.472 \\
Air temperature $\left({ }^{\circ} \mathrm{C}\right)$ & 29.10 & 29.60 & 30.02 \\
Relative humidity $(\%)$ & 49.81 & 52.34 & 53.36 \\
Internal roof tile temperature $\left({ }^{\circ} \mathrm{C}\right)$ & 38.52 & 39.82 & 43.29 \\
\hline
\end{tabular}

The main component analyses of both strains showed the presence of moderate associations 


\section{Pereira DF, Vitorasso G, Oliveira SC, Kakimoto SK, Togashi CK, Soares NM}

between production and the environmental conditions measured four to one day before eggs were produced. This means that there were associations between production and average daily environment, but there was not a single day in which environment and production were strongly associated. Figure 3 shows the main component graphs of the association between production and environment on the day before eggs were laid for the strains Dekalb ${ }^{\circledR}$ White (a) and HyLine ${ }^{\circledR}$ w36 (b).
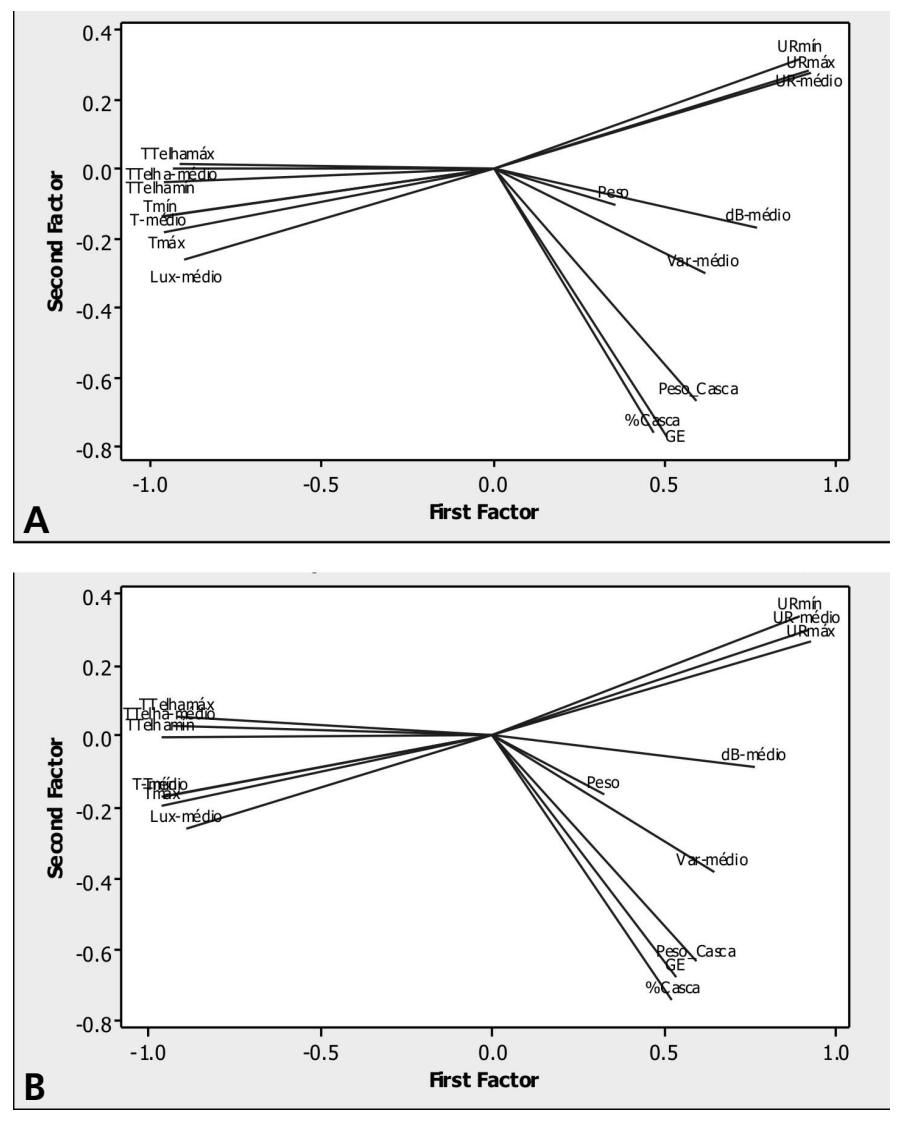

Figure 2 - Main component graphs of production and environmental parameters on the day eggs were laid of Dekalb ${ }^{\circledR}$ White (a) and Hy-Line ${ }^{\circledR}$ w36 (b) strains.

Legendas: dB-média=dB-mean; Lux-média =Lux-mean, Varmédia=AirV-mean, Peso=Weight, Peso Casca $=$ Eggshell weight, $\mathrm{T}$ média $=$ T-mean, Tmáx $=$ Tmax, Tmín=Tmin, URmédia=RHmean, URmáx=RHmax, URmín=RHmin, TTelhamédia= TTile-mean, TTelhamáx= TTilemax, TTelhamín= TTilemin

Figure 3 é shows moderate negative association between egg quality parameters and environmental variables. Lin et al. (2006) asserted that high environmental temperatures are very stressful to poultry, and affect their productivity. This productivity reduction, according to Macari et al. (1994) and Nääs (1989), may be measured as quality loss of the
Correlations between Thermal Environment and Egg Quality of Two Layer Commercial Strains

produced eggs. When Figure 2 is compared with Figure 3 , it is observed that increases in air temperature and in internal roof tile temperature caused lower eggshell percentage, eggshell weight, and specific gravity values, resulting from the negative association between these two groups of variables. This association between qualitative production variables and air temperature was also observed by Hsu et al. (1998).
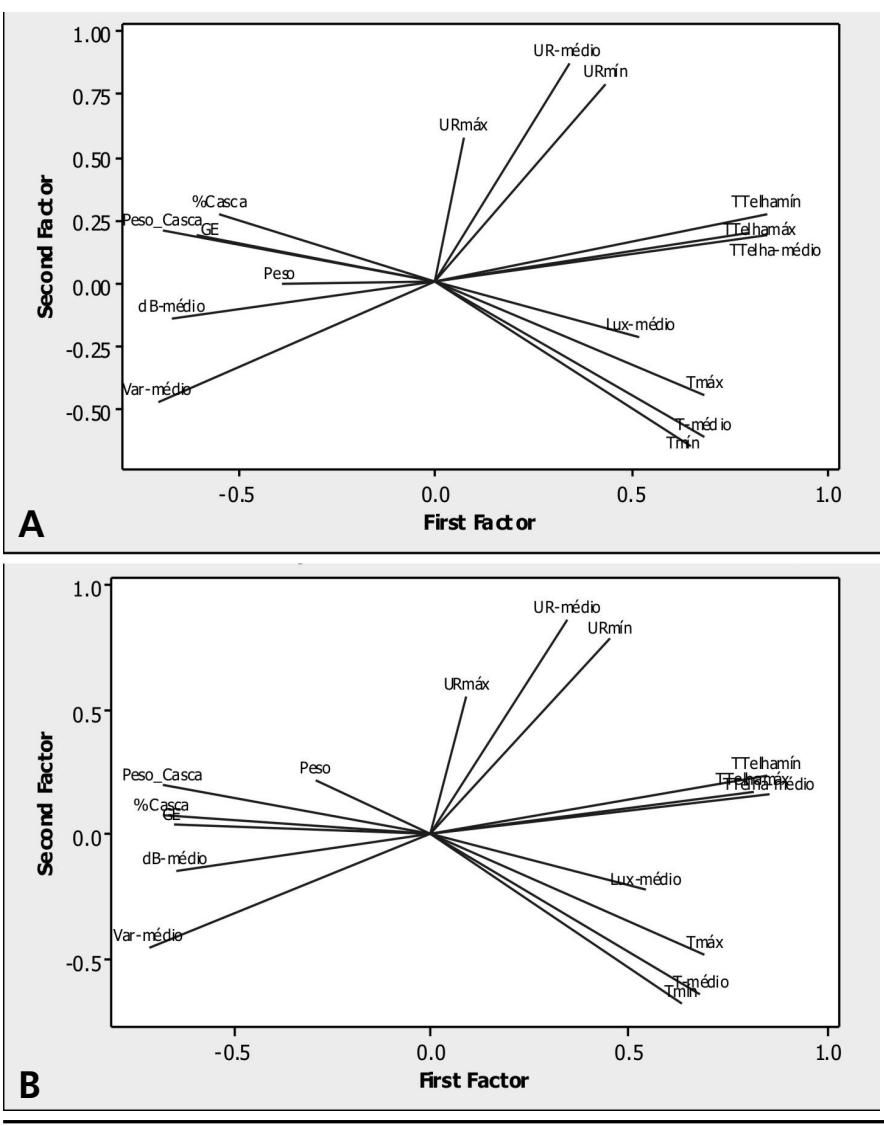

Figure 3 - Main component graphs of production and environmental parameters on the day before eggs were laid of Dekalb $^{\circledR}$ White (a) and Hy-Line ${ }^{\circledR}$ w36 (b) strains.

Figure 3 also shows a positive association between sound intensity and production parameters. Sound intensity, as measured inside the house, included several components, such as external noise and machines working inside the house - background noise, and noises produced by the birds, among which vocalizations are highlighted. Although a more detailed analysis of the measured sound waves was not performed, it was observed that bird vocalization was the sound that most contributed for the variation of measured sound intensity. The analysis of Figure 3 showed that the increase of sound intensity inside the house was strongly associated with an improvement 


\section{Pereira DF, Vitorasso G, Oliveira SC, Kakimoto SK, Togashi CK, Soares NM}

Correlations between Thermal Environment and Egg Quality of Two Layer Commercial Strains of the quality of the eggs produced on the next day. This result could indicate that sound intensity could be used as a parameter to estimate the welfare of caged layers. However, further studies are required to evaluate the effects of this variable and of bird vocalization on layer welfare to validate this hypothesis.

The relation between noise produced by poultry and welfare was reported by Manteuffel et al.(2004), who related vocalization to certain emotional states. The authors said that, because vocalization is closely related to the physical-physiological status of the animal, it may be used as a non-invasive method to estimate welfare. Zimmerman et al. (2000) observed significant differences in the vocalization of layers submitted to different feeding regimes, with more frequent vocalization when hunger increased. Marx et al. (2001) related layer emotional state with different vocalization types during the process of gradual bird isolation, and concluded that this process resulted in an increase in vocalization related to stress.

For egg weight (EW), due to the low magnitude of its vector in the main component plan of all analyses, no evidences that confirm the existence (or not) of associations between this parameter and the other analyzed variables were found, which is consistent with the results of Muiruri \& Harrison (1991). Mashaly et al. (2004) also tested the effect of three environmental conditions on the production performance of layers in the peak of lay (31 weeks of age). The following conditions were tested: thermoneutrality (constant temperature of $24^{\circ} \mathrm{C}$ ); cyclic, simulating natural conditions of hot months (temperature varying between 23.9 and $35^{\circ} \mathrm{C}$ ); and heat stress (constant temperature of $35^{\circ} \mathrm{C}$ ). The authors concluded that heat stress significantly influenced egg weight; however, no significant differences between thermoneutral and cyclic temperature on egg weight were observed after five weeks of continuous exposure.

Differences between strains were observed in the analyses of two, three, and four days before egg production. In order to further explore these data, Pearson's correlation tests ( $r$ ) were carried out between variable pairs at a significance level of $1 \%(P<0.01)$. Tables 2 and 3 show these results, and the significant results $(r>0.5)$ are highlighted.

The main component graphs shown in Figure 2 and Figure 3 (environment on the day eggs were produced and the day before, respectively) and the Pearson's correlations in Tables 2 and 3 indicate that light intensity did not affect egg quality, as shown by Renema et al. (2001).
Franco-Jimenez et al. (2007) and Vits et al. (2005) detected significant differences in eggshell quality between different layer strains submitted to different heat stress levels, suggesting that genetic strains have different acclimatization capacity and eggshell stabilization times. These differences can be observed in Tables 2 and 3, which show that all qualitative production parameters were influenced by the environment $(P<0.01)$.

\begin{tabular}{|c|c|c|c|c|c|}
\hline $\begin{array}{l}\text { Ta } \\
\text { eg } \\
\text { an } \\
\text { the }\end{array}$ & $\begin{array}{l}\text { e } \mathbf{2} \text { - Pears } \\
\text { weight (EW } \\
\text { eggshell per } \\
\text { days before }\end{array}$ & $\begin{array}{l}\text { correlat } \\
\text { ecific g } \\
\text { age (ES } \\
\text { were }\end{array}$ & $\begin{array}{l}\text { betwe } \\
\text { (SG), } \\
\text { ind en } \\
\text { or Dek }\end{array}$ & $\begin{array}{l}\text { roductic } \\
\text { shell we } \\
\text { nental } \\
\text { White s }\end{array}$ & $\begin{array}{l}\text { ariables } \\
\text { (ESW), } \\
\text { bles on }\end{array}$ \\
\hline & & EW & SG & ESW & ES\% \\
\hline & dB-mean & - & - & 0.292 & - \\
\hline & Lux-mean & - & 0.290 & 0.333 & 0.297 \\
\hline & AirV-mean & 0.324 & 0.430 & 0.528 & 0.408 \\
\hline$\stackrel{\varrho}{\varrho}$ & T-mean & - & -0.326 & -0.375 & -0.317 \\
\hline$\stackrel{0}{2}$ & Tmax & - & -0.258 & -0.296 & -0.265 \\
\hline$\frac{\omega}{n}$ & Tmin & -0.258 & -0.348 & -0.435 & -0.330 \\
\hline त & RH-mean & -0.313 & -0.432 & -0.490 & -0.371 \\
\hline $\begin{array}{l}0 \\
\sim\end{array}$ & RHmax & -0.264 & -0.406 & -0.420 & -0.306 \\
\hline & RHmin & -0.314 & -0.412 & -0.516 & -0.412 \\
\hline & TTile-mean & - & -0.292 & -0.314 & - \\
\hline & TTilemax & - & -0.293 & -0.305 & - \\
\hline & TTilemin & -0.317 & -0.267 & -0.356 & - \\
\hline & dB-mean & - & - & - & - \\
\hline & Lux-mean & - & - & - & - \\
\hline & AirV-mean & 0.335 & 0.423 & 0.505 & 0.353 \\
\hline & T-mean & -0.287 & -0.333 & -0.430 & -0.313 \\
\hline 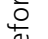 & Tmax & -0.291 & -0.340 & -0.417 & -0.286 \\
\hline قـ & Tmin & -0.224 & -0.423 & -0.488 & -0.446 \\
\hline$\overbrace{\vec{\sigma}}^{n}$ & RH-mean & -0.325 & -0.424 & -0.470 & -0.328 \\
\hline$\frac{\pi}{0}$ & RHmax & -0.286 & -0.341 & -0.382 & -0.254 \\
\hline & RHmin & -0.324 & -0.531 & -0.577 & -0.470 \\
\hline & TTile-mean & - & -0.320 & -0.343 & -0.265 \\
\hline & TTilemax & - & -0.290 & -0.309 & - \\
\hline & TTilemin & - & -0.397 & -0.404 & -0.344 \\
\hline & dB-mean & - & - & - & - \\
\hline & Lux-mean & - & -0.363 & -0.323 & - \\
\hline & AirV-mean & 0.294 & 0.367 & 0.450 & 0.338 \\
\hline & T-mean & -0.260 & -0.349 & -0.454 & -0.388 \\
\hline 훈 & Tmax & -0.272 & -0.274 & -0.390 & -0.298 \\
\hline مـ & Tmin & -0.276 & -0.408 & -0.506 & -0.432 \\
\hline$\stackrel{n}{\pi}$ & RH-mean & -0.315 & - & -0.377 & - \\
\hline$\frac{\pi}{0}$ & RHmax & - & - & - & - \\
\hline 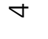 & RHmin & -0.351 & -0.343 & -0.499 & -0.354 \\
\hline & TTile-mean & - & -0.499 & -0.467 & -0.400 \\
\hline & TTilemax & - & -0.470 & -0.432 & -0.373 \\
\hline & TTilemin & -0.259 & -0.487 & -0.492 & -0.394 \\
\hline
\end{tabular}

where: $\mathrm{dB}-$ mean $=$ mean sound intensity on that day $(\mathrm{dB})$; Lux-mean $=$ mean light intensity on that day (lux); AirV-mean = mean horizontal air velocity on that day dia $(\mathrm{m} / \mathrm{s})$; T-mean $=$ mean air temperature on that day $\left({ }^{\circ} \mathrm{C}\right)$; $T$ max $=$ maximum air temperature on that day $\left({ }^{\circ} \mathrm{C}\right)$; $\mathrm{Tmin}=$ minimum air temperature on that day $\left({ }^{\circ} \mathrm{C}\right) ; \mathrm{RH}$-mean = mean aire relative humidity on that day $(\%)$, $\mathrm{RH} \max =$ maximum air relative humidity on that day (\%); RHmin = minimum air relative humidity on that day $(\%)$; TTile-mean $=$ mean internal roof tile temperature on that day $\left({ }^{\circ} \mathrm{C}\right)$; TTilemax $=$ maximum internal roof tile temperature on that day $\left({ }^{\circ} \mathrm{C}\right)$; TTilemin $=$ minimum internal roof tile temperature on that day $\left({ }^{\circ} \mathrm{C}\right)$. 


\section{Pereira DF, Vitorasso G, Oliveira SC, Kakimoto SK, Togashi CK, Soares NM}

Correlations between Thermal Environment and Egg Quality of Two Layer Commercial Strains
Table 3 - Pearson's correlations between production variables egg weight (EW), specific gravity (SG), eggshell weight (ESW), and eggshell percentage (ES\%) and environmental variables on the days before eggs were laid for Hy-Line ${ }^{\circledR}$ w36 strain.

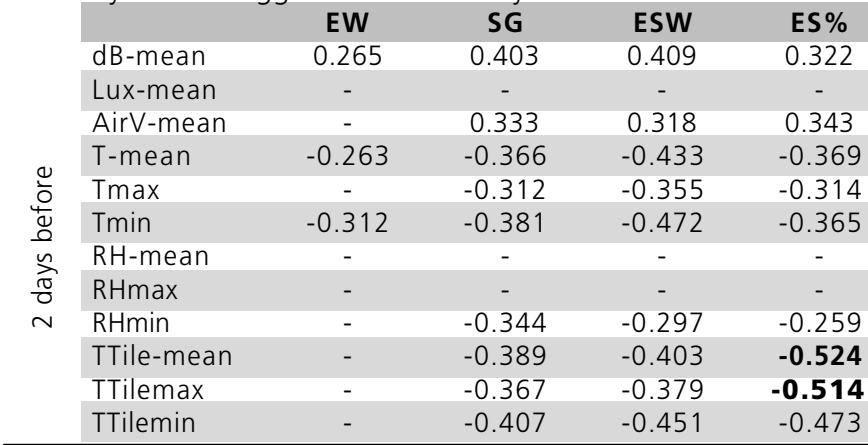

\begin{tabular}{|c|c|c|c|c|c|}
\hline \multirow{12}{*}{ 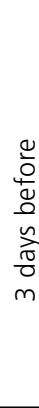 } & dB-mean & - & - & - & - \\
\hline & Lux-mean & - & - & - & - \\
\hline & AirV-mean & - & 0.539 & 0.549 & 0.572 \\
\hline & T-mean & -0.420 & -0.366 & -0.419 & - \\
\hline & Tmax & -0.378 & -0.389 & -0.442 & -0.270 \\
\hline & Tmin & -0.413 & -0.349 & -0.429 & - \\
\hline & RH-mean & -0.299 & -0.440 & -0.474 & -0.387 \\
\hline & RHmax & -0.264 & -0.363 & -0.393 & -0.311 \\
\hline & RHmin & -0.326 & -0.513 & -0.564 & -0.481 \\
\hline & TTile-mean & - & -0.348 & -0.348 & -0.490 \\
\hline & TTilemax & - & -0.328 & -0.320 & -0.465 \\
\hline & TTilemin & - & -0.390 & -0.405 & -0.529 \\
\hline \multirow{12}{*}{$\begin{array}{l}\frac{0}{0} \\
\frac{0}{0} \\
0 \\
\tilde{\sigma} \\
\frac{\sigma}{0} \\
\forall\end{array}$} & dB-mean & - & - & - & - \\
\hline & Lux-mean & - & -0.300 & -0.309 & -0.319 \\
\hline & AirV-mean & - & 0.427 & 0.472 & 0.478 \\
\hline & T-mean & -0.291 & -0.341 & -0.414 & -0.296 \\
\hline & Tmax & - & -0.320 & -0.364 & -0.395 \\
\hline & Tmin & -0.380 & -0.408 & -0.479 & -0.292 \\
\hline & RH-mean & - & -0.375 & -0.396 & -0.407 \\
\hline & RHmax & - & - & - & -0.337 \\
\hline & RHmin & -0.307 & -0.490 & -0.528 & -0.450 \\
\hline & TTile-mean & - & -0.418 & -0.464 & -0.525 \\
\hline & TTilemax & - & -0.386 & -0.433 & -0.510 \\
\hline & TTilemin & - & -0.441 & -0.491 & -0.555 \\
\hline
\end{tabular}

where: $\mathrm{dB}$-mean $=$ mean sound intensity on that day $(\mathrm{dB})$; Lux-mean $=$ mean light intensity on that day (lux); AirV-mean = mean horizontal air velocity on that day dia $(\mathrm{m} / \mathrm{s}) ; \mathrm{T}$-mean $=$ mean air temperature on that day $\left({ }^{\circ} \mathrm{C}\right) ; \operatorname{Tmax}=$ maximum air temperature on that day $\left({ }^{\circ} \mathrm{C}\right)$; $\mathrm{Tmin}=$ minimum air temperature on that day $\left({ }^{\circ} \mathrm{C}\right) ; \mathrm{RH}$-mean $=$ mean aire relative humidity on that day $(\%)$; RHmax = maximum air relative humidity on that day (\%); RHmin = minimum air relative humidity on that day $(\%)$; TTile-mean $=$ mean internal roof tile temperature on that day $\left({ }^{\circ} \mathrm{C}\right)$; TTilemax $=$ maximum internal roof tile temperature on that day $\left({ }^{\circ} \mathrm{C}\right)$; TTilemin $=$ minimum internal roof tile temperature on that day $\left({ }^{\circ} \mathrm{C}\right)$

No correlation between sound intensity measured three and four days before egg lay (Tables 2 and 3) with production parameters was detected, except for Dekalb ${ }^{\circledR}$ White, which eggshell weight showed a week correlation with this variable two days before egg was laid (Table 2). Tables 2 and 3 show that egg production had different correlations with environmental variables in both strains as a function of egg formation stage. Two and three days before production, air velocity and relative humidity presented positive and negative correlations, respectively, with egg specific gravity, eggshell weight, and eggshell percentage, for both strains. Three days before production, for the strain Hy-Line ${ }^{\circledR}$ w36, roof tile temperature had a negative correlation with egg quality parameters (Table 3 ), and four days before production, production parameters were correlated with air temperature and internal roof tile production, particularly, for both strains. Production parameters of Hy-Line ${ }^{\circledR}$ w36 layers presented higher correlation values.

\section{CONCLUSIONS}

It was observed that air temperature, relative humidity, horizontal air velocity, and internal roof tile temperature affected egg quality at different intensities during egg formation and at different stages of egg formation in each genetic strain.

The low ammonia concentrations measured inside the poultry houses showed the efficiency of natural ventilation and air renewal in the monitored facilities, and did not affect egg quality.

\section{REFERENCES}

Campos EJ. Avicultura: razões fatos e divergências. Belo Horizonte(MG): Editora FEPMVZ; 2000.

Crivisqui E. Presentación del análisis de componentes principales. Seminário de métodos estadísticos multivariados aplicados às ciências humanas; 1998; Campinas,São Paulo. Brasil. Campinas(SP): Instituto de Economia da Unicamp; 1998.

Esmay ML. Principles of animal environment. Westport: Avi Pusblishing Company; 1982.

Franco-Jimenez DJ, Scheideler SE, Kittok RJ, Brown-Brandl TM, Robeson LR, Taira H, Beck MM. Differential effects of heat stresss in three strains of laying hens. The Journal of Applied Poultry Research 2007; 16(4):628-634.

Hsu JC, Lin CY, Chiou PW. Effects of ambient temperature and methionine supplementation of a low protein diet on the performance of laying hens. Animal Feed Science and Technology; 1998; 74:289-299.

Johnson RA, Wichern DW. Applied multivariate statistical analysis. 4thed. NewJersey: Prentice Hall; 1998.

Lin $\mathrm{H}$, Jiao HC, Bbuyse J, Decuypere E. Strategiess for preventing heat stress in poultry. Poultry Science 2006; 62(1):71-85.

Macari M, Furlan RL, Gonzales E. Fisiologia aviária aplicada a frangos de corte. Jaboticabal(SP): FUNEP/UNESP; 1994. 
Manteuffel G, Puppe B, Schön ESW. Vocalizations of farm animal as measure of welfare. Applied Animal Behaviour Science 2004; $88(1-2): 163-182$

Mashaly MM, Hendricks GL, Kalama MA, Gehad AE, Abbas, AO, Patterson PH. Effect of heat stress on production parameters and immune responses of commercial laying hens. Poultry Science, 2004, 83:889-894.

Marx G, Leppelt J, Ellendorff F. Vocalisation in chicks (Gallus gallus dom.) during stepwise social isolation. Applied Animal Behaviour Science 2001; 75(1):61-74.

Muiruri HK, Harrison ESW. Effectt of roost temperature on performance of chickens in hot ambient environments. Poultry Science 1991; 70(11):2253-2258.

Nääs IA. Fatores não nutricionais que afetam o desempenho de frangos de corte. Anais da Conferência Apinco de Ciência e Tecnologia Avícolas; 1992; Santos. São Paulo. Brasil. Campinas: Fundação Apinco de Ciência e Tecnologia Avícolas; 1992.

Nääs IA. Princípios de conforto térmico na produção animal. São Paulo:Ícone; 1989.

Nääs IA, Miragliotta MY, Baracho MS, Moura DJ. Ambiência aérea em alojamento de frango de corte: poeira e gases. Engenharia Agrícola 2007; 27(2):326-335.

Remena RA, Robinson FE, Feddes JJR, Fasenko GM, Zuidhoft MJ. Effects of ligth from photostimulation in four strains of commercial egge layers: 2. Egg production parameters. Poultry Science 2001; 80(8):1121-1131.

Santos PA, Yanagi Jr. T, Texeira VH, Ferreira L. Ambiente térmico no interior de modelos de galpões avícolas em escala reduzida com ventilação natural e artificial dos telhados. Engengaria Agrícola 2005; 25(3):575-584.

Teeter RG, Belay T. Broiler water balance and thermobalance during thermoneutral and high ambient temperature exposure. Poultry Science 1993; 72(1):116-124.

Tinôco IFF. Avicultura industrial: novos conceitos de materiais, concepções e técnicas construtivas disponíveis para galpões avícolas brasileiros. Revista Brasileira de Ciência Avícola 2001; 3(1):1-25.

Vits A, Weitzenbürger D, Hamann H, Distl O. Production, egg quality, bone strength, claw length and keel bone deformities of laying hens housed in furnished cages with different group sizes. Poultry Science 2005; 84(10):1511-1519.

Wathes CM, Jones JB, Kristensen HH, Jones EKM, Webster AJF. Aversion of pigs and domestic fowl to atmospheric ammonia. American Society of Agricultural Enginners 2002; 45(5):1605-1610.

Zimmerman $\mathrm{PH}$, Koene $\mathrm{P}$, van Hooff JARAM. The vocal expression of feeding motivation and frustration in the domestic laying hen, Gallus gallus domesticus. Applied Animal Behaviour Science 2000; 69(4):265-273. 